\title{
ONLINE MARKETING IN POLITICAL COMMUNICATION - ITS ESSENCE, INSTRUMENTS, AND FUNCTIONS Anna Karwacka
}

\begin{abstract}
Online marketing is nothing else than a model of traditional marketing in cyberspace; it is a hybrid of previous forms of mass communication. In the first decade of the 21 st century, the instruments used in marketing in political communication were revolutionized by the emergence of solutions enabling the interactions of users on the Internet. This type of marketing is characterized by a range of concepts, and includes online advertising campaigns, websites, interactive social networks, video-sharing sites, which encourage users to regularly post new material, websites that enable the publication of photos, images and other files or those that are based on content provided by users i.e. Wikipedia (including blog sites). Contemporary, internetized election campaigns combine low costs with effectiveness because location no longer limits social contacts in the exchange of election-related information.
\end{abstract}

Key words: online marketing, political communication, website, social network, blog, election campaign

\section{Introduction}

Political communication is an integral part of a political system functioning in the social space. It is the fundamental process of the information-based influence of political representatives on society.

This article is a theoretical review. It aims to identify key aspects of the political communication process, to review the Internet marketing tools used by politicians, and to explain the influence the media have on shaping the interactions taking place within political communication. The research method applied can be defined as a descriptive analysis based on knowledge gathered as a result of a critical review of literature in the field of political marketing.

Another issue analyzed is the effectiveness of specific promotional tools. The focus was on which tools reach the largest number of recipients, which are the best for shaping a politician's image. The article also presents the relation between costs and effectiveness of the particular tool.

The main hypothesis assumes that politicians or their political marketing specialists continually adapt and use the Internet tools to get the feedback and interaction enabling mutual, open communication. However, the efficient use of political communication tools depends on the politicians' online activity and their reaction speed.

Also, it can be assumed that modern politicians continue to lack sufficient knowledge in the field of Internet promotion. 
Due to the complexity of the subject, conclusions from case studies were applied.

Jacques Gerstlé argues that politics could not function without a communication process and that interpersonal relations would also not exist without communication [Gerstlé, 2016, pp. 13-15]. In analyzing political communication, Spanish Marie José Canel also emphasizes that the practice of politics is based primarily on skillful communication. Furthermore, Dominique Wolton defines political communication as an antonym to lowering the rank of politics and, moreover, as a requirement for the functioning of a broadly defined public space [Wolton, 2015, p. 256]. On the other hand, the professionalization of communication accompanies the implementation of marketing basics into policy areas [Neveu, 2012, p. 68]. Given the rapid and multipolar development of the media and the fact that the media are considered to be the fourth power, communication instruments are becoming an inseparable element of political life [Michalczyk, 2005, p. 17].

A form of political communication that deals with creation and exchange of values between political actors is online marketing.

The importance of the Internet in political marketing will continue to grow together with the generational change of Polish voters. This is because Internet users belong to the category of citizens who actively participate in political elections. It should be noted that according to surveys conducted in 2017, the Internet access of Polish households amounted to 81.9\% [Główny Urząd Statystyczny, 2017], which is over 16 million Internet users in Poland between 16 and 74 years of age [Główny Urząd Statycznyczny, 2017]. This applies to the range of people who are in the voting group. Given that campaigns can last up to two years, and sometimes even the entire term, sixteen-year-olds reach the age of majority in time to vote for their favorite.

A feature of the measures that fall within online marketing conducted in parallel to traditional marketing is a reduction in the costs of communication activities. The key importance is the fact that specific content can be immediately posted online without printing and distributing materials.

Given the use of online marketing instruments in political communication, it must be highlighted that it is much easier to identify voters' profiles (regardless of the traditional segmentation of the political market) and to analyze their base. Currently, available tools enable detailed analysis of potential voters who enter candidates' websites and are interested in their election programs. Every electoral politician can independently obtain such data - for example, by browsing Google Analytics statistics, conducting surveys, using an external entity or through an advertising agency or experts appointed by the electoral committee.

The increasing impact that candidates have on the Internet content improves the effectiveness of reaching active voters with political messages. Knowing the needs, expectations, and opinions of voters within a given social group, it is possible to target the group with well-formulated messages and to apply effective measures. In addition, social contacts in the area of exchange of election-related communications can spread faster and, most importantly, without being limited by location.

Another area for analysis is the diversification of the models of fees for purchased advertisements. In this respect and in the context of money spent, specialists can analyze the effectiveness of campaigns much more accurately. One of the most popular tools is a cost-per-mille (CPM) ${ }^{2}$, which is an indicator used in planning and analyzing the effectiveness of advertising campaigns on the Internet. CPM shows the average cost per click on an advertising banner or sponsored link by 1,000 Internet users, compared with the entire budget allocated to the advertising campaign. Another frequently used method of paying for advertising is a cost-per-click, where the advertiser pays when an 
Internet user clicks on a banner or another form of online advertising. The lower the CPC, the lower the average cost an advertiser must incur for each banner view.

However, an Internet campaign is useful only if the candidate is prepared to be regularly active online and provide quick responses. This is because Internet users are not patient, and quickly become discouraged in the absence of information or contact. Neither buying ads nor targeting the relevant target group will bring the expected results if the candidate does not get involved.

\section{Websites}

Nowadays, websites are a standard in the process of communication with voters and media representatives. They are considered to be the cheapest information channel that, at the same time, provides the publisher with full control over the content of the message. One's website must be positioned, regularly updated, and promoted. The address of a politician's official website is usually found on all printed election materials, banners, and roll-ups that form the backdrop at appearances.

Bearing in mind the scale of marketing activities that form part of an election campaign, a politician may decide to use one of several possible types of official websites. To choose the most appropriate type of website, the candidate must take into account the Internet penetration rate of the voters in a given electoral district and, in particular, the target group he/she intends to reach. If this indicator is weak and modest, then simple activities should be implemented, such as launching a website, usually presenting the candidate's program and political profile. In a medium-scale online campaign, a website also includes the social aspect, where voters have the opportunity to communicate with each other, contact the candidate and his/her staff, as well as use various types of information exchange tools at their disposal. The website contains more multimedia elements, offers more functionalities, and the blog run by the candidate does not have to be connected to his/her official website. When implementing a large-scale online campaign, it is beneficial to also implement an extranet for supporters ${ }^{3}$ in order to convince them to participate in the candidate's campaign. This way, the social aspect is maximized. A website presents the candidate, his/her election program, and other elements of the election message as efficiently as possible using a range of multimedia tools such as video materials with the candidate's speeches, animations and other interactive content [Trétarre, 2012, p. 449].

A candidate's website is visited by several categories of the Internet users characterized by their relationship to the election campaign. These can include the candidate's supporters, activists who monitor progress and participate in the exchange of messages, political opponents obtaining information on the campaign, and the undecided voters who are looking for information about the candidate or the journalists looking for a potential article topic. Representatives of each of those categories have their expectations and different needs as to the content of the candidate's official website. In large-scale campaigns, websites are clearly dedicated to the key target groups of the candidate. The style, content, vocabulary, and messages are adapted to the recipients. This makes them a more useful tool in the hands of the content publisher than general pages that must meet the expectations of all - often opposing - target groups. Such an approach requires creative methods both for the creation of a website and its management by the campaign staff, as well as for conducting relevant communication [Trétarre, 2012, p. 450].

\footnotetext{
3 Extranet - a closed computer network based on internet protocols designed for the exchange of information with business partners. The goal of creating extranets is to make private resources available between organizations (enterprises), or between them and their clients, while preventing universal access from the internet - https://pl. wikipedia.org/wiki/Ekstranet (accessed on: February 19, 2017)
} 
A website has a variety of roles. The first and main one is its information function, which involves providing information to voters about the candidate, the ticket they are running on, the party they represent, and their program. It envisions the building of the politician's image through graphics and visual features, the page layout, and its ergonomics. A site is also a tool for circulating information. The candidate uses it to present his/ her opinion on current issues, comment on the views and attitudes of competitors, and provide information to journalists. It can also be used to collect online data and recruit supporters by forms completed by the users. The candidate's website is also an ideal platform to create a virtual community or to learn the opinions of the Internet users via polls. The site is also one of the leading places to which the candidate's supporters are directed during the election campaign.

The website's ergonomics include its maneuverability and the ease with which visitors can find the information they seek and learn about its functionalities. It is usually assessed from the point of view of a user, not its creators or electoral staff. Ideally, the site should be tested by neutral users. Poor ergonomics results in a negative perception and prevent website visitors from finding information. The intuitiveness of the site is disrupted. Menu bars must be clear and understandable to the general online community. Images should be coherent with the content, and the hierarchization of information must be clear and to the point [Trétarre, 2012, p. 452].

Feedback on the popularity and functionality of the website is also invaluable. A ready website is usually registered in a system that enables statistical analysis - most often in the free Google Analytics. These type of tool help obtain information on the number of views, visits, keywords based on which users find the page, and on the location of people entering the site, their gender, age, etc. [Proniewicz, 2014, p. 36]

Politicians usually create domains using their name with their country's suffix (in Poland - pl, in France - fr, etc. In response to the intuitive searches of the Internet users, the candidates and their election committees register other available domains that may be associated with them during the election campaign.

\section{Blogosphere and vlogosphere}

Blogosphere is a term that defines all blogs as a community or social network. Individually run blogs can be linked together, allowing authors to leave comments on the related to the content entries, or to link them. Blogs can have their own distinctive culture. It can be assumed that blogs are a type of publication, while the blogosphere has become a social phenomenon.

The term 'blogosphere' was first used on September 10, 1999, by Brad L. Graham [Dash, 2010]. On the other hand, the word 'blog' was created from the combination of the words 'web' and 'log', which means a type of website containing separate, usually chronologically ordered entries. The readers of a given online journal or blog can usually archive, categorize, tag, and also comment on entries.

According to Judy Strauss and Raymond Frost, who refer to data from Dazelnfo. com, in 2011 the total number of blogs in the world exceeded 181 million. It was approximately 146 millions more than in 2006 [Strauss, Frost, 2016, p. 339]. On the other hand, in 2013, there were already almost 317 millions of blogs on the Internet. ${ }^{4}$ In addressing the issue regarding politics, the blogosphere is co-created by the authors of blog sites and/or political blogs, active commentators and passive readers.

The candidate's blog is a less formal communication tool than the typical website because it is considered to be an online journal containing daily entries, or entries at other intervals that can be viewed by anyone interested. The candidate does not always run his/her blog. Often, a political party's blog has articles published by several or more peo-

4 Infogram, [online: December 2, 2017] https://infogr.am/number-of-blogs-worldwide: 
ple who are also responsible for stimulating and activating the entire blog community. Candidates use their blogs to present their points of view and voice facts that should not adversely affect their political image. Publishing a biography or referring to details about the candidate's personal life is not appropriate during a political campaign. Providing too much strictly election-related information is also not an optimal solution. Politicians should work on their image in the context of social accessibility - always being close to the people. From the perspective of propaganda, the essential value of contact is the feeling of intimacy in the voter-candidate relationship.

In the blog, which is a tool in the hands of the candidate during the election campaign, opinions are usually expressed on topics that are either only superficially touched upon or not addressed at all in the election messages [Trétarre, 2012, p. 440]. Political bloggers use this tool both for their vested interests and group interests. Blogs provide information and promote the author, but can also be used in campaigns negatively.

How does the classic blogosphere differ from the political one? Of course, in addition to the subject matter, comments play a much more significant role. The elements of a classic blog are usually notes added by the authors, and comments left by the Internet users. Classic blogs do not mean much and do not play an advisory role. On the other hand, political blogs are meant to encourage discussion.

In his research, K. Karnkowski reiterated that the increasing importance of the role of comments is confirmed by the technical possibility of tracking new opinions. It is worth noting that RSS readers are programs designed to support information channels that can be found on most websites. They send news headlines directly from websites to web browsers so that the Internet users do not have to use the web browser to download their favorite web pages in order to read the latest information, and can find out when new content on a given topic is posted on the website they are following [Karnkowski, 2012, p. 16].

RSS feeds enable sending of news headlines from websites to readers. It is a practical solution because all one has to do is to add sources from websites to the RSS reader. This way, the information channels are refreshed at specified intervals.

For a blog to be fully effective and bring the desired results, it must generate an increasing number of new visitors, extend the duration of the individual visits to the blog site, as well as increase the frequency of visits and visitors' activity. The number of new blog readers is not a sufficient indicator to assess the effectiveness of visits to the site. It is also necessary to know the recipients of the blog content. Visits to the blog by the Internet users who are not part of the target group, except for some special cases, are not useful to the election campaign. Because of the quantitative aspect, the blog should use graphics and publish content to reflect the appropriate image and attitude of the politician. Visitors often place links on other websites. Such activities bring obvious benefits if the Internet users use a search engine to find a website about the candidate or political party.

When analyzing the duration of a blog visit, the more time a visitor spends on the site, the more information they can receive. If the Internet user does not quickly find the information they seek, their visit to the website will be very short. That is why various methods are used to facilitate surfing the blog's site and making access to information in a comfortable, fast and intuitive way. For this purpose, internal search engines, article classification, and keywords associated with entries are used [Trétarre, 2012, pp. 441443]. Individual blogs play the role of Hyde Park, enabling commenting on the electoral initiatives taken up by competing candidates. Therefore, links to other blogs (blogrolls) should play an integral role. Links from other blogs improve the frequency of visits to a page (PageRank) and, thus, the position of the blog in the Google search engine.

It is also necessary to take into account the form and message conveyed by the title, and the first sentence of the article. It is the title that usually attracts the attention 
of the Internet users and encourages them to read several sentences of the introduction. As a result, an interesting introduction will make the visitor read the entire text. Illustrations reinforce impressions and make the text more credible, enabling the visualization of the discussed topics. By combining the article with the logbook, the blogger establishes almost direct communication with another person, including expressing even his/her intimate thoughts. Philippe J. Maarek believes that all blogs should contain at least two elements that increase their interactivity, i.e., the possibility of conducting a dialog with the Internet users. The first is a discussion forum that allows connected Internet users to respond to published posts. The second essential element is the link zone connecting 'friendly' sites or ones that are the most interesting. Blogs like most Internet messages are based on hypertext (text that places links and references to other content), which allows a smooth transition between various information and topics. Hypertext provides the recipient with 'freedom of movement', and changes the way content is consumed from linear to non-linear. Those links shape the blogosphere. The key here is the number of links to other blogs that are the most popular and, theoretically, the most influential. In today's era, specialized software can 'map' the blogosphere topic by topic [Maarek, 2014, p. 333].

According to S. Trzeciak, besides interactivity, information must be up-to-date and look professional. Every entry containing 300-500 words published several times a week should have an attractive, intriguing title, and (usually) be dated. It is worth using short sentences, straightforward language, bullet points, photos, video recordings, and the above-mentioned internal links. Promoting the blog both online and offline is essential. However, S. Trzeciak warns against setting up a blog 'for the sake of it' if one does not have the time or the will to run it. [Trzeciak, 2014, p. 221]

There are increasingly more free blog platforms; however, in the context of political campaigns, the advertisements integrated with them undoubtedly distract readers. The range of content management systems that allows the administration of blogs is equally extensive. Examples include Spip - www.spip.net, Joomla! - www.joomla.fr, Dotclear fr.dotclear.org, Drupal - drupal.org, Wordpress - www.wordpress-fr.net [Allard, 2012, p. 46] and, in Poland, wordpress.com, blogspot.com, blogger.pl, and joomla.pl.

Research conducted by K. Karnkowski from the University of Warsaw regarding the political blogosphere shows that not all sites that publish blogs should be considered blog platforms. Blogs are often part of larger sites (such as interia.pl, onet.pl, and wp.pl), or are something additional to information sites related to magazines (for example, Wprost.pl and Niezalezna.pl). It should be noted that those sites focus mainly on the news, interesting comments and opinions, not on blogs. Therefore, while the blogosphere includes the blogs mentioned above and their authors, it does not include websites as a whole. Besides blogs, there are also 'aggregates'. Initially, they played a major role; however, as the website market expanded their significance declined remarkably. Nowadays, a better method of aggregating blogs is Multi-Author Blog. MABs are websites that do not publish their blogs but acquire bloggers' publications in various places online and publish them in one place. Aggregates are usually addressed to people with specific political views. The users can find on such sites texts (previously scattered on the Internet) by authors representing a similar point of view. The history of aggregates goes back almost as far as the history of the Polish political blogosphere. As they developed and increased in popularity, some aggregates began publishing their own materials and evolved into independent blog platforms [Karnkowski, 2012, p. 13].

Rafał Wiśniewski and Marcin Zarzecki list blogs as useful tools in local elections due to minimal costs of reaching the potential voters with candidates message. Another advantage is the lack of restrictions regarding space for publishing information because blogs contain current and archived data. Also, blog creators can diversify the content. Information can be transmitted anywhere at any time thanks to the spread of the Internet via mobile devices (iPads, iPods, palmtops, cell phones, netbooks). 
The authors list a range of measures that can be implemented via blogs. One of them is the ability to connect one's blog to a vertical portal - a specialized portal publishing information in the field of politics. Another feature is the possibility of microblogging - giving voters brief information about candidate's thoughts and opinions, as well as information on the dates of debates or meetings with voters.

Including a blog in an election campaign also facilitates contact with journalists. This type of medium is prevalent among media representatives. Experience shows that politicians stimulate the interest of the media in all respects during the pre-election period, and this is always an element of the campaign desired by politicians [Wiśniewski, Zarzecki, 2015].

\section{Social media}

In the literature on the subject, social media fall within the category of technologies that provide easy-to-use CMS mechanisms ${ }^{5}$, enabling publishing of visual and audio content on the Internet. Social media are also referred to as a hybrid of previous forms of mass communication [Faracik-Nowak, 2013, p. 18], a collection of websites and applications that enable the users to interact with their friends [Brown, 2012, p. 21]. They initiated the era of Web 2.0 sites with the implementation of model practices into politics, feedback, and platforms for virtual discussions.

Online marketing researchers emphasize the benefits of using the Internet in political communication. According to Magdalena Faracik-Nowak, the central aspect of online tools are: interactivity and two-way communication (as opposed to traditional media), the co-existence of vertical and horizontal communication, promoting equality, the lack of the role of a journalist, low costs, transmission speed, and global reach [FaracikNowak, 2013, p. 19].

There are social networking sites and applications (for example, Facebook and Snapchat), discussion forums and groups, blogs and microblogs (for example, Twitter), instant messengers, chat rooms, photo publishing sites, sites for creating and publishing videos, virtual worlds, and virtual social games [Lupa, 2016, pp. 22-23].

Modern election campaigns that do not use social media seem to be not effective anymore. Referring to the research on the use of social media in enterprises by Iwona Lupa, an analogy can be made to refer to the distinctive characteristics of measures during election campaigns. A large number of users is crucial for the candidate. According to data from January 2016, 14 million users were registered on social media in Poland (over one-third of Poland's population), this number increased by $8 \%$ compared with the previous year [Digital in 2016]. The heads of electoral teams and specialists involved in running the campaigns are not able to directly control led in the Internet discussions concerning candidates; however, they have a number of tools for engaging potential voters, influencing the direction of those discussions, and shaping them to suit the candidates' campaign strategies [Lupa, 2016, p. 24]. It is possible thanks to blogs, vlogs, citizen journalism, and social knowledge bases (wiki).

Politicians can also publish a short dossier in their profiles. In this category, websites such as Facebook, LinkedIn, and GoldenLine take the lead. The attention should be brought to the time between the creation of content and its publication or disclosure, which, in the case of social media, is immediate, and any delays depend only on the users of the site [Kaznowski, 2014, p. 77]. Kaznowski highlights that the information that is well suited to the needs of the recipients gets wider distribution.

\footnotetext{
5 (Content Management System) - a system that supports the management of the information content of a website or page, without requiring any specialist knowledge of programming or website development. It is a system designed to maximize the ease of managing and processing information (author's note)
} 
Another form of the interaction is sharing the resources about the candidates and their programmes. Sites that enable the users to view, store and share photos, videos or presentations are Flickr, Instagram, YouTube, and Slideshare.

Politicians seeking an electoral mandate also focus on contact with the local community by commenting on current events. The best tools in this category are Twitter and live stream services, and livecasts [Miotk, 2016, pp. 84-85]. Also, alert services or SMS notification systems are often widely used by current presidents or mayors who want to reapply for the office.

The candidate should have a profile or page on several social networks. When analyzing the use of social media in the political environment, Michat Lange states that politicians are now beginning to discover the significance and effectiveness of such media. One thing to know about the existence of new communication tools, and another to know how to use them effectively, for example, in an election campaign. Although an increasing number of politicians are beginning to appreciate the power of the Internet, the number of those who can use it efficiently is increasing at a much slower rate [Internetowe kampanie wyborcze, 2013]. Politicians still do not fully realize that the key to success is an active online presence and a well-planned strategy of using the available social media tools. Some political parties in Poland perceive this kind of communication only as an additional one to the traditional election-related activities.

Summarizing the analysis of online marketing tools, it should be emphasized that their multi-channel use in political communication is related to the activity of the politician. The selection of tools depends on the strategy adopted for the political campaign. Taking into account the entire range of possibilities, it can be assumed that this area of politicians' activities will be entrusted to experts, or that the politicians will acquire the experience of using online instruments.

\section{References}

ALLARD PH. (2012), Gagnez les élections avec Internet, Liège, Edi.pro, Editions des CCI SA; BROWN E. (2012), Working the Crowd: Social Media Marketing for Business, BCS, Swindon;

DASH A. (2010), A blog about making culture, [online: December 2, 2017] http://anildash.com/2010/01/ remembering-brad-I-graham.html;

Digital in 2016 - Special Reports [online: December 4, 2016] http://wearesocial.com/uk/special-reports/digitalin-2016;

FARACIK-NOWAK M. (2013) Kampanie wyborcze w dobie mediów społecznościowych [in:] M. Kolczyński, Współczesne kampanie wyborcze w Polsce: koncepcje, dylematy i praktyka komunikowania politycznego, GNOME - Wydawnictwo Naukowe i Artystyczne, Katowice;

GERSTLÉ J. (2016), La Communication politique, Paris, Armand Colin, Collection: Cursus Science politique; Gtówny Urząd Statystyczny (2017), Opracowanie sygnalne. Społeczeństwo informacyjne w Polsce w 2017 r.,

Warszawa, 20.10.2017 [online: November 30, 2017], https://stat.gov.pl/obszary-tematyczne/nauka-i-technika-spoleczenstwo-informacyjne/spoleczenstwo-informacyjne/spoleczenstwo-informacyjne-w-polsce-w2017-roku,2,7.html;

Gtówny Urząd Statystyczny (2017), Polska w liczbach. Maj 2017 [online: November 30, 2017] https://stat.gov.

pl/files/gfx/portalinformacyjny/pl/defaultaktualnosci/5501/14/10/1/polska_w_liczbach_2017.pdf;

Infogram, [online: December 2, 2017] https://infogr.am/number-of-blogs-worldwide;

Internetowe kampanie wyborcze [online: December 3, 2016] http://doradztwomedialne.pl/prasa/internetowe-

kampanie-wyborcze.

KARNKOWSKI K. (2012) Blogosfera polityczna w Polsce, rozprawa doktorska, Warszawa, Uniwersytet

Warszawski Instytut Stosowanych Nauk Społecznych, [online: February 17, 2017] https://depotuw.ceon.pl/

handle/item/242;

KAZNOWSKI D. (2014) Social media - społeczny wymiar Internetu [in:] eds. Królewski J., Sala P., E-marketing. 
Współczesne trendy. Pakiet startowy, Warszawa, , Wydawnictwo PWN;

LUPA I. (2016) Media społecznościowe w marketingu i zarządzaniu. Wybrane zagadnienia z teorii i praktyki przedsiębiorstw, Katowice, Wydawnictwo Naukowe Sophia;

MAAREK P. J. (2014) Communication et marketing de l'homme politique, Paris, LesisNexis SA;

MICHALCZYK S. (2005), Komunikowanie polityczne. Teoretyczne aspekty procesu, Katowice, Wydawnictwo Naukowe "Śląsk";

MIOTK, A. (2016), Nowy PR. Jak internet zmienił public relations, Lublin, Wydawnictwo Słowa i Myśli;

NEVEU É. (2012), Les mots de la communication politique, Toulouse, Presse Universitaire du Mirail;

PRONIEWICZ J (2014), Kampania samorządowa w internecie, Warszawa, Gazeta Samorządu i Administracji nr 17/2014 z 2014-09-05, Grupa INFOR PL;

STRAUSS J., FROST R. (2016) E-Marketing, London and New York, Routledge Taylor \& Francis Group;

TRÉTARRE F. (2012), Campagnes Électorales. Principes et pratiques de la préparation et de la conduite de campagnes, Paris, Gualino éditeur, Lextenso éditions;

TRZECIAK S. (2014) Drzewo kampanii wyborczej czyli jak wygrać wybory, Sopot, Gdańskie Wydawnictwo Psychologiczne Sp. z 0.0.;

WOLTON D. (2015), La communication, les hommes et la politique, Paris, CNRS Éditions, coll. „Biblis”;

WIŚNIEWSKI R., ZARZECKI M., Wykorzystanie marketingu internetowego w kampanii wyborczej, INFOR [online: February 19, 2017] http://samorzad.infor.pl/sektor/rozwoj_i_promocja/marketing/462833,Wykorzystanie-marketingu internetowego-w-kampanii-wyborczej.html; 